ADDIN, Volume 13, Number 2, August 2019

\title{
Pesantren-Based Madrasah: \\ Curriculum Implementation Model \\ and Integrative Learning
}

\author{
M. Ihsan \\ Institut Agama Islam Negeri (IAIN) Kudus, Indonesia \\ ihsan_dr12yahoo.co.id
}

\begin{abstract}
This study aims to analyze curriculum implementation design and Islamic Education learning, a variety of curriculum integration and Islamic Education learning, and pesantren-based madrasah model that is appropriate with National Education Standard and users' expectations. This research was a qualitative study with a naturalistic paradigm which philosophically referred to phenomenological post-positivism and used social action models. This research was conducted in Kudus Regency with subjects related to institutional reality, curriculum implementation, learning and human resources of Madrasah Alijah (MA) or Islamic Senior High Schools. The results showed that pesantren or Islamic boarding school is a model of MA management which madrasah and pesantren management are operationally managed in one management system. It means that MA is not only physically located in pesantren, but MA and pesantren are in an integrated organizational and management structure. The purpose of this management system unification is that all educational processes are in a system that allows all teachers and students activities in the same program package. It will ultimately create a holistic education process that produce the quality education output and outcome. Thus, the willingness to make pesantren as an Islamic education curriculum basis is based on the need to maximize the true Islamic education curriculum.
\end{abstract}

Keyword: Pesantren-Based Madrasah, Curriculum, Integrative Learning. 
Abstrak

MADRASAH BERBASIS PESANTREN: MODEL IMPLEMENTASI KURIKULUM DAN PEMBELAJARAN INTEGRATIF. Penelitian ini bertujuan untuk mengetahui: desain implementasi kurikulum dan pembelajaran Pendidikan Agama Islam (PAI), ragam integrasi kurikulum dan pembelajaran PAI, serta model madrasah berbasis pesantren yang kompatibel dengan Standar Nasional Pendidikan dan ekspektasi masyarakat pengguna. Penelitian ini merupakan penelitian kualitatif dengan paradigma naturalistik yang secara filosofis mengacu pada post-positivisme phenomenology dan menggunakan model social action. Penelitian ini mengambil lokasi di Kabupaten Kudus dengan subjek terkait dengan realitas kelembagaan, implementasi kurikulum, serta pembelajaran dan sumber daya manusia MA di Kudus. Hasil penelitian menunjukkan bahwa Madrasah Pesantren merupakan model pengelolaan Madrasah Aliyah (MA) yang secara operasional pengelolaan antara madrasah dan pesantren berada dalam satu sistem manajemen. Artinya, suatu MA tidak hanya secara fisik berada dalam lingkungan pesantren, tetapi antara MA dan pesantren berada dalam satu struktur organisasi dan manajemen yang menyatu (integrated). Tujuan dari penyatuan sistem pengelolaan ini adalah agar semua proses pendidikan berada dalam suatu sistem yang memungkinkan semua kegiatan guru dan murid berada dalam satu alur dan paket program yang sama yang akhirnya akan tercipta proses pendidikan holistik yang akan melahirkan autput dan outcome pendidikan berkualitas. Dengan demikian, kehendak untuk menjadikan pesantren sebagai basis kurikulum PAI lahir dari kebutuhan untuk memaksimalkan kurikulum pendidikan Islam yang sesungguhnya.

Kata Kunci: Madrasah Berbasis Pesantren, Kurikulum, Pembelajaran Integratif.

\section{A. Introduction}

Historically, madrasah or Islamic School as an educational institution is the modernization and transformation of traditional Islamic educational institutions, namely pesantren or Islamic Boarding School. ${ }^{1}$ Culturally, pesantren is a form of adaptation

\footnotetext{
${ }^{1}$ Nurcholis Madjid, Bilik-bilik Pesantren (Jakarta: Paramadina, 1997), 23.
} 
and Islamization of the pre-Islamic education system of the Hindu-Buddhist era. ${ }^{2}$ In the traditional historiography illustration, pesantren is religious education institution that becomes a reference for developing pious values based on Islam. Pesantren alumni are expected to be generations with individual and social piety who can become examples and preaching cadres to the community. ${ }^{3}$ As an educational and religious institution with a great tradition, pesantren have proven their work in educating the people. ${ }^{4}$

Over time, pesantren as an educational institution are seen as less able to equip their students with practical competencies to work, especially for the formal sector. This fact encourages Muslim leaders from Middle Eastern graduates to create a new educational format by adopting a Western school system under the name of madrasah or Islamic School. The existence of madrasah as a form of pesantren education system modernization was motivated by at least three things, namely: (1) efforts to reform Islamic education in response to the politics of the Dutch East Indies education to indigeneous people, (2) the overly strong orientation of pesantren education system to the religious sciences ('ubudiyyah) and less attention to social, political, economic, cultural and other practical abilities, (3) pesantren education system was seen as not systematic when it was compared to the school system introduced by the Dutch colonialism so its education system was not recognized because it was considered not giving pragmatic abilities to the students. ${ }^{5}$

In independence era, especially in New Order Era, pesantren began to get the government attention under the Ministry of Religion auspices, management and supervision. Important and

${ }^{2}$ M. Habib Moestopo, Kebudayaan Islam di Jawa Timur: Kajian Beberapa Unsur Budaya Masa Peralihan (Yogyakarta: Jendela, 2001), 150.

${ }^{3}$ Joko Sayono, "Historiografi Pesantren: Perspektif Metodologis antara Ada dan Tiada", Paper, Not Published, 2001, 3.

${ }^{4}$ Martin van Bruinessen, Kitab Kuning, Pesantren, dan Tarekat: Tradisi-tradisi Islam di Indonesia (Bandung: Mizan, 1995), 17.

${ }^{5}$ Maksum, Madrasab: Sejarah dan Perkembangannya (Jakarta: Logos, 1999), 114. 
strategic policies from the government to improve institutions and management, among others, are through formalizing policies and structuring pesantren. ${ }^{6}$

Madrasah as Islamic educational institutions are now placed as school education in the national education system. The emergence of Surat Keputusan Bersama (SKB) or Joint Ministerial Decree of the Three Ministers indicated that the existence of Madrasah is already strong enough like public schools. The emergence of the Three Ministerial Decree was also seen as a positive step to improve the quality of Madrasah in terms of status, qualification grades, and curriculum. The existence of Madrasab in the National Education System has become more juridical and stronger with the issuance of Law Number 20 Year 2003 concerning the National Education System. In this law, Madrasah and schools have the same position. ${ }^{7}$

Nationally, as a public school with the distinctive characteristics of Islam, Madrasab is expected to become an educational institution with its comparative advantage, namely a significant emphasis on religious and moral education. Moreover, it also teaches general subjects. With these characteristics, it is hoped that Madrasab will be able to become an alternative education in the midst of community anxiety about the lack of religious value understanding in daily life. Another positive thing that supports the superiority of Madrasah is the tendency fact to Islam and the emergence of the rise of Muslim middle class in society that are increasingly trying to get quality Islamic education for their children. ${ }^{8}$ This fact is as an opportunity and challenge for Madrasab to be able to meet the society needs and expectations, especially parents who want their children to obtain

\footnotetext{
${ }^{6}$ Departemen Agama RI, Profil Madrasah Aliyah (Jakarta: EMIS Religious Department of RI, 2005), 9-14.

${ }^{7}$ A. Malik Fadjar, Madrasah dan Tantangan Modernitas (Bandung: Mizan cooperated with YASMIN Bogor, 1998), 28.

${ }^{8}$ Azyumardi Azra, Surau: Pendidikan Islam Tradisional dalam Transisi dan Modernisasi (Jakarta: Logos, 2003), 54.
} 
adequate religious and general knowledge, particularly at Madrasah Aliyah (MA) level. So they can have both of them in balance.

Based on the writer's observation, both as a practitioner and an academic, who is directly or indirectly involved in Islamic education activities, it is found that the ideals of Madrasab in Kudus with all the exellences and strengths are not yet fully realized. Some Madrasah have indeed showed their exellences, but this fact did not describe the general Madrasah situation. It was not surprising when there were many Madrasab that were unable to implement the curriculum in accordance with the proportions that should be, among others due to limited time (duration or frequency), human resources (managers, teachers, or other education personnel), facilities and infrastructure or an educational environment that was less conducive to the ongoing process of quality education. The high number of miss-match teachers in certain fields, the lack of learning time allocation, the low ability to master the religious knowledge of Madrasah graduates, and the high number of failure in National Examination were realities that need attention and a solution. It is not surprising when the community evaluates that most of the current MA graduates lose their identity in accordance with the historical context of their existence as an educational institution for cadre candidates. Meanwhile, the mastery or achievement of learning outcomes in the field of science or general knowledge is far behind from Senior High School or Sekolah Menengah Atas (SMA) students.

In order to reach and complete the deficiencies, a phenomenon emerged in several Islamic Senior High Schools in Kudus that they organize the education system by adopting the pesantren education system. This step was taken, among others, to increase learning duration. It is hoped to enable the process of strengthening and enriching curricular materials according to content standards. Special for PAI or Islamic education material, this system is used as a medium for the implementation of curriculum development, both in terms of 
subject matter as well as the learning system and model. The results, problems and solutions of the program are important for further study.

On the basis of these considerations and realities, as practitioner and academic, writer was encouraged to know these phenomena while offering solutions to the various problems. Furthermore, this article discusses three issues related to Pesantren-based Madrasah problems, namely: (1) curriculum implementation design and PAI learning of MA in Kudus, (2) various curriculum integration and PAI learning, (3) model of Pesantren-based Madrasah that meets Standards National Education and community expectations.

\section{B. Discussion}

\section{Islamic Education Essence and Purpose}

Islamic education is essentially always defined as a process to form Muslim who are knowledgeable, faithful and devoted to Allah. According to Musthofa and Ally, Islamic education is a guiding process from educators to the students' physical, spiritual, and intellectual development to be Muslim with good personality. ${ }^{9}$ The conception of Islamic education is built on the basis of metaphysics, where the relationship between God as creator and human being as subjects on earth is in a series of religious orientations and ethical frameworks. According to al-Ghazali, this religious-ethical framework characterizes the concept of Islamic education. Even so, it does not mean worldly affairs are not important, but worldly affairs and all their happiness are only supporting factors to achieve happiness that is more important and lasting. The world is a field to the hereafter. It is a place of wandering and a means to God Almighty, not a place to stay and live. ${ }^{10}$ Starting from this understanding, it can be seen that the purpose of Islamic education is to form people

${ }^{9}$ Ahmad Musthofa Aly and Abdullah, Sejarah Pendidikan Islam untuk. Fakultas Tarbiyah Komponen MKDK (Bandung: Pustaka Setia, 1998), 11.

${ }^{10}$ Al-Ghazali, Ihya' 'Ulum ad-Din (Beirut: Dar al-Ma'rifah, 1993), 24. 
who are aware of and carry out the Caliphate tasks and enrich themselves with science. However, Islamic education also realizes that the whole nature of life and the knowledge is from and into God Almighty. ${ }^{11}$

\section{Pesantren Education System}

According to K.H. M.A. Sahal Mahfudz, pesantren is an Islamic educational institution that has at least seven elements. They are the kiai or religious teacher who teaches and educates, students who study, mosque as a place of worship and education, pesantren as a place for students to live, Islamic books as a source of study, management, and pesantren as a system. ${ }^{12}$ Important points and focus that need to be examined in pesantren definition according to K.H. M.A. Sahal Mahfudz is that pesantren as a system becomes the main axis and social, cultural, and religious dynamics of Islamic society. In fact, pesantren has formed a new sub-culture that is sociologicallyanthropologically can be regarded as a pesantren community. A further elaboration of this statement is that the so-called pesantren there are not merely physical forms of religious learning, with building facilities, kitab kuning, santri, and kiai, but also the wider community that lives around them and forms patterns of cultural, social, and religious relations.

There is something that stands out as a characteristic possessed by traditional pesantren, which is only giving religious lessons in Arabic versions of classical Islamic books, teaching techniques with sorogan and bandongon or wetonan methods. In addition to the two methods, Mastuhu called memorization and halaqah as a learning method in pesantren. ${ }^{13}$ Madrasah and classical systems are applied

${ }^{11}$ Muslih Usa (ed.), Pendidikan Islam di Indonesia: Antara Cita dan Fakta (Yogyakarta: Tiara Wacana, 1991), 9.

${ }^{12}$ H.M. Arifin, Kapila Selekta Pendidikan: Umum dan Islam (Jakarta: Bina Aksara, 1991), 249.

${ }^{13}$ Mastuhu, Dinamika Sistem Pendidikan Pesantren XX (Jakarta: INIS, 1994), 61. 
to make teaching techniques easier. It was as sorogan and bandongan method development. ${ }^{14}$ It does not mean that sorogan and bandongan methods are increasingly ineffective. On the other hand, the method is tactically-methodical in the context of achieving learning outcomes proven to have high effectiveness and significance. It is effective because this system allows a kiai or cleric to supervise, evaluate, and guide santri in mastering the material maximally. The effectiveness of bandongan system lies in the practical needs of achieving the quantity and acceleration of book study. In addition, it is also for having close relations between santri or students and the kiyai or teacher. Nevertheless, every method must have weaknesses. ${ }^{15}$

\section{Madrasah Education System}

The word "madrasab" comes from Arabic, which means school. Epistemologically, the word madrasah comes from the word "darasa" which means a place to sit for learning. In its development, the word madrasab is not only interpreted as a school, but also includes the understanding of the school (Islamic education). ${ }^{16}$ Madrasab is a form of modernization of pesantren education. This institution also has a large role in the history of education development in Indonesia. Zakiyah Daradjat stated that the rise of Madrasah was the beginning of formal institutionalization of Islamic education. ${ }^{17}$

In the world of pesantren, there are well-known key elements of pesantren, namely kiai, santri, pondok or dormitory, mosque, and Islamic education learning. In madrasah system, it is not a must to have a cottage, mosque, and study of classical books. Preferred

${ }^{14}$ Ahmad Tafsir, Ilmu Pendidikan dalam Perspektif Islam (Bandung: Remaja Rosdakarya, 1992), 194.

${ }^{15}$ Zamakhsyari Dhofier, Tradisi Pesantren: Studi Tentang Pandangan Hidup Kyai (Jakarta: LP3ES, 1990), 50.

${ }^{16}$ W.J.S. Poerwadarminta, Kamus Umum Bahasa Indonesia (Jakarta: Balai Pustaka, 1999), 618.

${ }^{17}$ Zakiyah Daradjat, Madrasab: Sejarah dan Perkembangannya (Jakarta: Logos Wacana Ilmu, 1999), vii. 
elements in Madrasah are leaders, teachers, students, hardware, software, and Islamic education learning. ${ }^{18}$

Based on the curriculum, madrasah can be divided into three types, namely: Madrasah Diniyah, Madrasah, and Madrasah Keagamaan (Religious Madrasab). Madrasah Diniyah is a form of madrasah that only teaches the religious sciences (diniyah). This Madrasah is intended as a religious education institution provided for students studying in public schools. This Madrasab is divided into three levels of education, namely: Madrasah Diniyah Awaliyah, Madrasah Diniyah Wustha, and Madrasah Diniyah Ulya. The second type of Madrasah is a Madrasah or a school that is characterized by Islam. This Madrasah consists of Madrasah Ibtidaiyah, Madrasah Tsanawiyah, and Madrasah Aliyah. The program is the same as a school, but the number of Islamic Education in madrasah is more than public schools. Madrasah Keagamaan is a madrasah at the secondary education level that prioritizes the mastery of students knowledge about religious teachings. ${ }^{19}$

The implementation of madrasah management will encompass seven Madrasab components like in schools. In addition to the seven components above, Mansur Muslich added six other components of the school/madrasab that are included in madrasah management as quoted by Jaja Jahari, namely: madrasah quality, madrasah leadership, madrasah policy, madrasah innovation, madrasab supervision, and education services marketing in Madrasah. Good and bad management of those components will also affect the quality of inputs, processes, and outputs in the Madrasah.

\section{Design of Curriculum Implementation and Islamic Education Learning in Madrasah Aliyah (MA)}

Pendidikan Agama Islam (PAI) or Islamic Education design at Madrasah Aliyah (MA) in Kudus is based on the spirit and values

${ }^{18}$ Haidar Putra Daulay, Historisitas dan Eksistensi: Pesantren, Sekolah, dan Madrasah (Yogyakarta: Tiara Wacana, 2001), 59.

${ }^{19}$ Daulay, 62. 
of pesantren. It is as a major part of the Islamic tradition and fulfills the qualifications of National Education Standards. The material taught in Madrasah is not only the same, but it is integrated with the material taught in pesantren. Because Madrasah education starts in the morning, the afternoon to evening activities are basically for adding and strengthening the material taught in the morning. In this case, the evening learning, namely the pesantren model, aims to explore or even develop Madrasab curriculum. This is considered important because Madrasab curriculum must indeed be refined or enriched with the pesantren curriculum. Pesantren can refer to the use of primary sources of classical Islamic education, in the form of kitab kuning, as a mandatory reference for learning.

Curriculum integration or even maximizing the Islamic education teaching or ulum ad-din through the pesantren system, is a necessity to maximize Islamic education. It must be done because Madrasah, especially Madrasah that are not based on salafi education, only use secondary sources as the learning reference. In non-salafi Madrasah, there is no obligation to explore Islam to the roots of classical teachings. Islamic materials taught in Madrasab is often in its concise and general form. Learning in Madrasab is only about understanding the religious sciences that are still elementary and have not yet reached the level of mastery or the ability to read the classical books written in kitab kuning. For the purpose of basic introduction in students, a brief and general introduction is recognized as quite helpful. However, when this pattern of knowledge transformation continues at the next level, through the formulation of material that is less explicitly classified, the result is less knowledge in mastering Islamic sciences. Moreover, two to three disciplines combined are not only each of them must be sorted individually, but sometimes also taught in a gradual level.

The limitation of the Islamic education curriculum seems to be caused by a pragmatic perspective in education, not a substantive 
view to explore Islamic scientific values comprehensively. Meanwhile, the pesantren curriculum contains the complexity of tool science. The teaching of the methodology of Islamic sciences, such as Usul Figh, 'Ulum Al-Qur'an, Ulum al-Hadith, Nahwu, Sharaf, Balaghah, and all elements of the methodology of Islamic sciences, prove that pesantren are very serious in exploring rich Islamic civilization. Methodologically, this scientific paradigm certainly goes against the limitations of very minimalist Madrasah curriculum. Madrasah as Islamic educational institutions that are formed based on Islamic values, both intellectual and spiritual values, should not be limited to conveying the ordinary Islamic knowledge. It is responsible to create students as Muslims who intellectually and morally have a strong Islamic character.

In the context of learning, social relations between teachers and students in Madrasab that are already functional and profane tend to no longer be sacred, such as the relationship of students and scholars who are still shaded by the concept of barakah. Because the nuances of the Madrasab tend to be formalist, normative or even spiritual content does not occur. In Madrasah, there is only didacticbureaucratic relations in a large system that is less concerned with the depth of psychic-spiritual content of Islamic education citizens. This is different from pesantren which bind didactic relations in a spiritual orientation. Thus, the relationship between the santri and the kiai ultimately is not formalistic. It is cultural and guarded by spiritual values in Islam. Therefore, in Islamic education, the teacher criteria must meet Islamic tradition standards. That is, a Madrasah teacher must have the character of Islamic teaching, like the character of a kiai. In this character, a teacher is not only in charge of delivering lessons from the textbooks. A teacher must also be positioned as an intellectual-spiritual guide for students. 


\section{Variety of Curriculum Integration and Islamic}

\section{Education Learning}

The Pesantren Madrasab Model is an ideal Islamic educational institution that unites the sincerity of Islamic values, intellect, understanding, and cultural togetherness, which is governed in modern administrative and bureaucratic management. At a more basic level, the Pesantren model will complete the our education character in general. It occurs mainly in the pragmatic orientation of the school system. In the Madrasab system which is based on the school system, education is oriented to the mastery of functional knowledge. That is, Islamic education is not only limited to the purpose of producing teaching staff in Islamic education. It can be seen from the procedural continuity among Madrasah graduates who mostly join Islamic universities, especially Tarbiyah Faculty. This functional orientation is certainly good, but it is inadequate if it is placed within a philosophical framework of knowledgeable goals in Islam.

These pragmatic and functional values must also be a concern and consideration for Madrasah managers in the operational activities of their education. Moreover, they must maintain the values and philosophy of Islamic education. The class system, in which students learn, should not be confined and limited to the class, but must also respond positively to phenomena that occur outside the classroom. Separating the learning process from the life space outside the classroom will make educational institutions uprooted from their roots and kept away from real life. If it happens, then educational activities, especially formal education, will limit its space for movement.

A big mistake happens when a student does not attend school then he considers that he does not need and have to study anymore. This problem can arise when there is no teacher coaching process due to various limitations, including due to lack of time for the process. If it happens, it will be a big problem for the Islamic education system. Therefore, the Islamic education system does not only 
pursue cognitive achievements, but it can shape the good character or morality. In addition, education does not only involve relationships with fellow human beings, but also relationships with Allah. If it is not done wisely, Islamic education will not only make the knowledge about Islam so low, but also have the opportunity to suppress the essence of Islam itself which demands a unity between science and charity. Knowledge can be limited in the classroom, but its practice must be as extensive as life itself. To see and understand the pesantren model, here are two figures of pesantren integration Pattern.

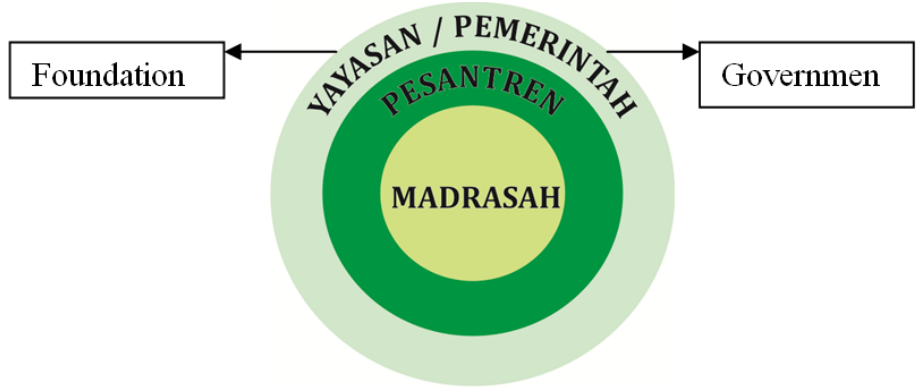

Figure 1

$1^{\text {st }}$ Pattern of Madrasah Pesantren Integration

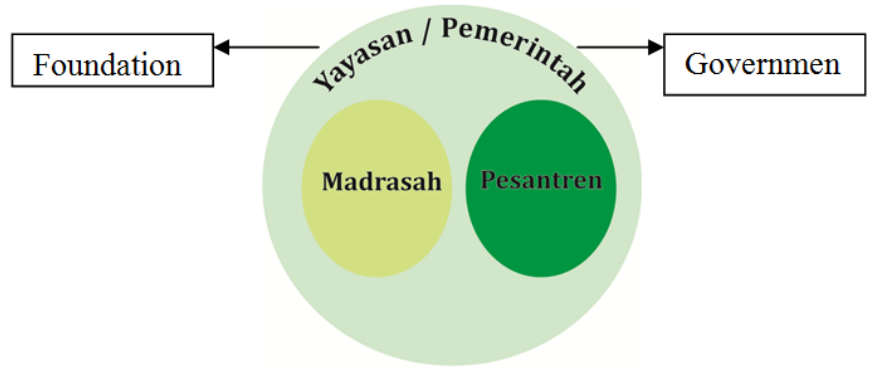

Figure 2

$2^{\text {nd }}$ Pattern of Madrasah Pesantren Integration

In this point, pesantren system will provide space and time for improving education in the classroom and strengthening education in all daily life. This educational model is also ideal for the initial 
formation of human personality because education is primarily for students character education. Pesantren model that gives students hospitality is the best way to maximize the educational process, especially Islamic education. It becomes logical because in Islamic education, just cognitive mastery is not enough. There must be social conditioning that makes students able to explore knowledge and practice it in their daily lives. The Pesantren Madrasab system that provides boarding and guidance after school will be able to meet these basic demands.

\section{Madrasah Pesantren Model in Accordance with National Education Standards and Community Expectations}

From the elaboration above, several concepts of developing the Madrasab Pesantren model are offered, which are theoretical findings from a review of the data, concepts and methodological possibilities that have been described above. First, pesantren can be established through normativising Madrasah based on pesantren values. That is, what is emphasized in this Madrasab Pesantren is the values of the pesantren as the basis for the development of Madrasab institutions. This departs from the fact that Madrasab has now been different from the roots of Islamic education (classical) in pesantren. Therefore, the construction of Madrasab Pesantren is an effort to return Madrasah educational institutions to the basic spirit of Pesantren as Islamic educational institutions that are still original.

The question is, what is called pesantren value as the basic value of the original Islamic education? In pesantren, religious learning is not always functionally motivated, but purely about studying religion for the betterment of a Muslim's life. In Madrasah, these pure intentions are often not realized by Madrasah residents because the paradigmatic construct of our formal education is pragmatic, not substantial. That is, the purpose of learning is not purely the finding for truth itself, 
but the motive of gaining expertise in order to work, for example as a religious teacher. In pesantren education, this functional motive is understood to be a causal impact and not a primary objective. The main purpose of students joining boarding schools is religious understanding so that students become Muslim kaffah.

Second, both the model and theoretical basis for the concept of pesantren education are the original nature of Islamic knowledge. In pesantren, the source of the knowledge that is imbued directly is taken from the book of Salaf (kitab kuning) by the great Islamic scholars. This is different from Islamic studies in Madrasah which often use secondary sources, namely in the form of Islamic textbooks formulated by the Ministry of Religious Affairs. The use of this original source of Islamic knowledge will produce two benefits. First, students will learn the truth of Islam directly from the original source, in the form of a book of salaf by the salaf scholars. Secondly, students will be processive in Arabic skills through reading Salaf book.

Third, the pattern and model of pesantren education is based on Islamic rationality. It means that the originality of Islamic knowledge is not only related to the knowledge source that comes from salaf book, but further in the rationality of Islamic knowledge. This factor that makes this concept offer trying to add and develop Figh subjects to Usul Fiqh, Al-Qur'an subjects to 'Ulum Al-Qur'an and Tafsir, and Akblaq subjects to Sufism. The addition and development of these subjects is related to the expansion of student understanding, from learning the knowledge product to methodology mastery that create the knowledge product. With Usul Figh, students will learn the methods of making Islamic law. With 'Ulum Al-Qur'an, students will be able to interpret the Qur'an based on historical context and scientifically valid reading methods. With Sufism, students will learn the practical ways to practice akblaq or morals. Islamic scientific methodology education will create the 
students who are able to think based on Islamic rationality because there is a typical rationality of Islamic civilization in the methodology.

Fourth, pesantren model forms the Islamic culture system. Through pesantren, we can form an Islamic cultural system. This is also related to the prerequisites of the pesantren model which do not stop at the normative level, but must be able to implement in institutional patterns and social interactions. This is what makes the placement of students in dormitory or in boarding schools to be vital. Because, through the boarding system as pesantren in general, Islamic education in Madrasah can be perfected, not only at the level of textual education, but also the formation of an Islamic social system. This social system will shape the students Islamic character. The unity among Islamic values, institutions and symbolic interactions will shape the Islamic cultural system.

The important thing that becomes the normative goal of the idea of Pesantren-based Madrasah model is the formation of Islamic systems and culture. This is important because as an educational institution, pesantren does not only function as educational institution, but also an organized Islamic society, both managerial and cultural normative. Pesantren will be the ideal type for an Islamic society formation that is based on the Islamic knowledge discipline which is practiced, not only individually, but also collectively. This practice, called the Islamic culture system, actually exists in pesantren. Therefore, pesantren is the modernization of the cultural system although the level is still limited. That is, this modernization is not blended to the modernization of pesantren values, but modernization at the managerial technical level by maintaining pesantren basis level. This modernization is related to the modernization of educational administration and institutional governance in the domain of the education bureaucracy.

This bureaucratic modernization is limited, but it does not eliminate the distinctive character of pesantren organization, which at one point retained the authority of the ulama. This finally became 
the fifth concept, namely the pesantren model which still held on to the authority of the ulama. In pesantren education, the highest authority is not in the hands of the Madrasah principal, but it is held by charismatic scholars who are recognized for their scientific credibility and spirituality. That is, the leadership structure in pesantren refers to two types of leadership, namely Syuriyah held by charismatic elderly ulama and Tanfizhiyah held by Madrasab principal. Tanfizhiyah works at the administrative leadership level of the institution, while Syuriyah works at the symbolic level of leadership. Symbolic leadership is very much needed in the Muslim community. Because, in Islam, the most important thing is the active religious element in the community. This religious activation is illustrated by the leadership of ulama who becomes a symbol for the Islamic sharia implementation. This symbolic leadership will also define Madrasah Pesantren as not merely secular educational institutions that are concerned with technical education, but with the religious orientation of the educational institution.

Sixth, pesantren model which is oriented to God. As we know, our formal education philosophy refers to John Dewey's philosophy of pragmatism. According to this philosophy, education is only a matter of humans learning to master something in order to cultivate nature and use it for survival. The ultimate goal of education, according to this understanding, is to regulate the way of processing the universe or so that humans increasingly master natural processing technology. This educational pragmatism is seen in our educational orientation which directs the goal attainment of the learning process to the ability to work in the industry, both the economic industry and the education industry itself.

From this point, the philosophy of Islamic education proposes an alternative orientation that focuses on hereafter. The theme of the hereafter is certainly not ignorance and indifference to the world. "Hereafter" here is in line with the term of divinity because what is called the world (ad-dunya) in Islamic terminology is anything 
other than Allah. (ma siwa Allab). Therefore, non-biased attitude is not interpreted as an attitude away from world life in the sense of economic-material progress, but rather non-biased attitude towards all beings other than Allah, which means their determination to only bring life to Allah. At this point, Islamic education plays an important role in knowing the path to (shariah) of Allah. The learning process in Islam ultimately aims not to get a job, but to understand the signs of His greatness and to find out the best way to become a servant ('abid) as well as a caliph (khalifah fi al-ardl) in accordance with God's will.

From this explanation, the orientation of pesantren education is certainly not industrial work, but knowledge processing so that students become qualified servants and caliphs. In playing this role, students can certainly become religious teachers (work orientation). However, the role of the teacher of religion is not understood as a pragmatic goal, but rather a mechanism to realize the function of the caliphate of a Muslim. This orientation must be really emphasized so that students do not get the wrong intention right from starting their motivation to learn. If the pesantren can do this, it will not just be able to reform education, but it is also capable to reform the way of life, from the pragmatic paradigm to the substantive divinity paradigm. Pesantren can eventually become the locomotive of fundamental changes in society structure, from a materialist society to a spiritual society. Here in lies the vitality of Madrasah Pesantren, not only at the level of education, but also for society and civilization quality in the future.

\section{Conclusion}

The limitation of Islamic Education or Pendidikan Agama Islam (PAI) curriculum in Madrasab seems to have been formed from a pragmatic perspective in education, not a substantive view to explore Islamic scientific values comprehensively. Meanwhile, the pesantren curriculum which contains the complexity of Islamic scholarship illustrates another reality. The teachings of Islamic methodologies 
such as Usul Figh, 'Ulum Al-Qur'an, 'Ulum al-Hadis, Nahwu, Sharaf, Balaghah, and all elements of Islamic scientific methodology prove that pesantren are very serious in exploring rich Islamic civilization. This methodological scientific paradigm certainly goes against the limitations of minimalist Madrasah curriculum. Thus, the willingness to make pesantren as the basis of Islamic Education curriculum existed from the need to maximize the true Islamic education curriculum.

Pesantren is a model of managing Madrasah Aliyah (MA), which is operationally managing Madrasab and Pesantren in one management system. MA is not only physically located in a pesantren environment, but between MA and pesantren, there is integrated organization and management structure. The purpose of this unified management system is that all educational processes are in a system that allows all teacher and student activities in same program package. This pesantren model is an ideal model for an educational process, not only for Islamic education (Madrasah), but also for all educational institutions in general. With this system or model, a holistic education process will be created and produces quality education output and outcome. 


\section{REFERENCES}

Aly, Ahmad Musthofa and Abdullah. Sejarah Pendidikan Islam untuke Fakultas Tarbiyah Komponen MKDK. Bandung: Pustaka Setia, 1998.

Arifin, H.M. Kapila Selekta Pendidikan: Umum dan Islam. Jakarta: Bina Aksara, 1991.

Azra, Azyumardi. Surau: Pendidikan Islam Tradisional dalam Transisi dan Modernisasi. Jakarta: Logos, 2003.

Bruinessen, Martin van. Kitab Kuning, Pesantren, dan Tarekat: Tradisitradisi Islam di Indonesia. Bandung: Mizan, 1995.

Daradjat, Zakiyah. Madrasah: Sejarah dan Perkembangannya. Jakarta: Logos Wacana Ilmu, 1999.

Daulay, Haidar Putra. Historisitas dan Eksistensi: Pesantren, Sekolah, dan Madrasah. Yogyakarta: Tiara Wacana, 2001.

Department of Religious Affairs, RI. Profil Madrasah Aliyah. Jakarta: EMIS Department of Religious Affairs RI, 2005.

Dhofier, Zamakhsyari. Tradisi Pesantren: Studi Tentang Pandangan Hidup Kyai. Jakarta: LP3ES, 1990.

Fadjar, A. Malik. Madrasab dan Tantangan Modernitas. Bandung: Mizan cooperated with YASMIN Bogor, 1998.

Al-Ghazali. Ibya' 'Ulum ad-Din. Beirut: Dar al-Ma'rifah, 1993.

Madjid, Nurcholis. Bilik-bilik Pesantren. Jakarta: Paramadina, 1997.

Maksum. Madrasab: Sejarah dan Perkembangannya. Jakarta: Logos, 1999.

Mastuhu. Dinamika Sistem Pendidikan Pesantren XX. Jakarta: INIS, 1994.

Moestopo, M. Habib. Kebudayaan Islam di Jawa Timur: Kajian Beberapa Unsur Budaya Masa Peralihan. Yogyakarta: Jendela, 2001.

Poerwadarminta, W.J.S. Kamus Umum Bahasa Indonesia. Jakarta: Balai Pustaka, 1999. 
Sayono, Joko. "Historiografi Pesantren: Perspektif Metodologis antara Ada dan Tiada", Paper, Not Published, 2001.

Tafsir, Ahmad. Ilmu Pendidikan dalam Perspektif Islam. Bandung: Remaja Rosdakarya, 1992.

Usa, Muslih (ed). Pendidikan Islam di Indonesia: Antara Cita dan Fakta. Yogyakarta: Tiara Wacana, 1991. 
M. Ihsan 